\title{
Study of Special Relationship \& Transfer Pricing in Indonesia
}

\author{
Lanny Kusumawati \\ Law Faculty, Surabaya University \\ Surabaya City, East of Java \\ Indonesia
}

\begin{abstract}
Transfer pricing is currently an important issue to be handled seriously by the Directorate General of Taxes in Indonesia, because the tax is the main income of the State, which is not only related to budget but also needs in the economic sector, so it needs clear rules, especially in handling multinational companies, which have special relations with domestic and foreign taxpayers as source countries.
\end{abstract}

A study of the special relationship in taxation is defined as a business relationship between two or more taxpayers and ultimately results in less payable income tax than it should be. This special relationship includes business, employment, ownership or equity participation, control, either through management or the use of technology.

Transfer pricing is often misused by business actors, by conducting transactions with an unreasonable value, despite all that, actually between the seller and the buyer have made a real price agreement, because the price paid by the buyer taxpayer to the seller's taxpayer does not match written. This is due to avoid paying high-income taxes.

The research method is a systematic investigation to increase the amount of knowledge, it is also a systematic and organized attempt to investigate certain problems that require answers. This research is qualitative, which intends to understand the phenomena experienced by research subjects such as behavior, perception, motivation, action and others holistically, and by means of descriptions in the form of words and language, in a special natural context. and by making use of various natural methods.

This type of research is normative, which is commonly referred to as doctrinal legal research or also called library research. It is called doctrinal law research because this research is only aimed at written regulations so that the research is very closely related to the library because this normative law will require secondary data in the library.

Transfer prices are a systematic manipulation of prices with the aim of reducing artificial profits, making it appear as if the company is losing money, avoiding taxes or duties in a country. Therefore, it is necessary to have a transfer price agreement between the taxpayer and the Directorate General of Taxes regarding the fair selling price of the products produced to parties who have a special relationship. This is to reduce the occurrence of transfer pricing misuse by Multi-National companies. What has been agreed between the taxpayer and the Directorate General of Taxes is the selling price of the products produced (fair value) and the number of royalties and so on.

Key words: Transfer Pricing, Special Relationship, Fair Value.

\section{INTRODUCTION}

In the era of globalization, trade is getting more and more complicated both within one's own country and in other countries, the relationship between one country and another is increasing and opening up. The ease of transactions through cyberspace is due to unstoppable technological advances and is so fast, it seems that there are no boundaries between countries. This concerns not only goods and services, but also includes capital and human resources.

From the aspect of taxation, this transaction is a major concern for taxpayers related to the source of income and the tax subject who receives the income is in 2 (two) different countries. Each country may impose a tax on income originating from transnational transactions, where the source of income originates or what is commonly called the source country. The source 
country has provided or provided public premises, goods and services, so that the tax subject can earn income. So the reason the source country collects taxes is the benefits that have been provided by the source country.

In the past, taxation in Indonesia was to regulate the budget, but now it has changed completely, because taxation knowledge has become globalized, has also developed along with technological advances, of course it is also related to individual needs in the economic field, so it needs clear rules, especially if the subject matters. Domestic taxes also have income from the source country (abroad) which can be connoted with a special relationship.

A special relationship (transfer pricing) is a relationship that occurs between 2 (two) or more taxpayers which causes the tax payable among the taxpayers to be smaller than what should be payable.

In fact, if traced, transfer pricing or this special relationship includes:

a. Domestic individual and private taxpayers;

b. Domestic individual taxpayers with foreign individual taxpayers;

c. domestic taxpayer and domestic corporate taxpayer;

d. domestic taxpayers and foreign corporate taxpayers;

e. Domestic corporate taxpayers and domestic corporate taxpayers;

f. Domestic corporate taxpayers and foreign corporate taxpayers;

g. Corporate taxpayers with domestic individual taxpayers;

h. Domestic corporate taxpayers with foreign individual taxpayers;

i. Taxpayers have direct or indirect equity participation of at least $25 \%$ in other taxpayers; the relationship between the taxpayer and the participation of at least $25 \%$ in two or more taxpayers; or the relationship between two or more of the latter taxpayers;

j. Taxpayers who have ownership relations in the form of equity participation of $25 \%$ or more directly or indirectly with other taxpayers are considered to have a special relationship.

k. Taxpayers control other taxpayers or two or more taxpayers are under the same control, either directly or indirectly.

1. Family relations, both blood and blood, are in a straight line and / or one degree to the side.

In a business activity and / or job that is affected by a special relationship, it is possible for a transaction to be carried out outside reasonable limits in accordance with the good customs of the trader. In business activities, the cost of assets to the buyer is the price actually paid and the selling price to the seller is the price actually received. However, with the existence of a special relationship, it causes the reported income to be less than what it should be for the seller or the imposition of costs more than what it should be for the buyer, so that tax avoidance can be easily carried out for parties who have a special relationship.

In order to further understand related parties with a special relationship in the taxation aspect, it is further regulated in Government Regulation of the Republic of Indonesia Number 94 of 2010 (hereinafter abbreviated to PP No. 94/2010) concerning Calculation of Taxable Income and Repayment of Income in the Current Year .

\section{THE PROBLEM}

From what has been stated in the description above, a problem arises that need to be discussed, namely "

(1) The emergence of a special relationship in practice

(2) Disclosure of the actual "Fair Value" in transactions or business activities between taxpayers as sellers and taxpayers as buyers. 


\section{STUDY OF LITERATURE}

\subsection{Transfer Pricing Understanding}

According to Charles T. Hongren: "Transfer price is the price one subunit (department or division) charges for product or service supplied to another sub-unit of the same organization"

According to the Directorate General of Taxes, pricing for the delivery of tangible goods, intangible goods, or the provision of services between related parties (affiliated transactions) "

This means that transfer pricing has a different meaning from a point of view, each taxpayer has a different perception. According to Gunadi, transfer pricing has a negative connotation as a bad business practice, namely the transfer of taxable income from a company owned by a multinational company to countries with low tax rates in order to reduce the total tax burden of the group. these multinational companies.

Preparing a Transfer Pricing Document that is comprehensive and is able to represent strong arguments when the tax authorities question the fairness of affiliate transactions, of course requires a deep understanding of various aspects ranging from understanding the concept of Transfer Pricing, determining affiliates, defining affiliate transactions, choosing a Tested Party, determining the method up to make conclusions on the fairness of the transaction. In addition, the ex-ante approach as outlined by PMK-213 is fundamental. If you apply this approach wrongly, you will be considered not applying the principles of fairness and business normality.

\subsection{Previous Research}

Hadi Setiawan (2012: 2) The forms of transfer pricing are intra-company and inter-company transfer pricing. Intra-company transfer pricing is transfer pricing between divisions within one company. Meanwhile, intercompany transfer pricing is transfer pricing between two companies that have a special relationship. The transactions themselves can be carried out in one country (domestic transfer pricing), or with a different country (international transfer pricing).

Darussalam and Sepriadi (2008) quote from Eden (2001) that they term transfer pricing manipulation with an activity to increase costs or lower invoices which aim to reduce the amount of taxes owed. Price manipulation that can be done by transfer pricing includes manipulation of:

- Sales price; -

- Purchase price;

- Allocation of general and administrative costs or overhead costs;

- Charging interest on loans by shareholders (shareholder loan);

- Payment of commissions, licenses, franchises, leases, royalties, fees for management services, fees for technical services, and fees for other services;

- Purchase of company assets by shareholders (owners) or related parties which are lower than the market price;

- Sales to foreign parties through third parties that lack / do not have business substance (such as: dummy companies, letter box companies or rein voicing centers).

Transfer Pricing, according to his book Darussalam, Danny Septriadi and Bawono Kristiaji, 2013, explained that the concept of transfer pricing can be applied for three different purposes.

(1) In terms of company law, transfer pricing can be used as a tool to increase efficiency and synergy between a company and its shareholders (Wolfgang Schon, 2014).

(2) In terms of managerial accounting, transfer pricing can be used to maximize the profit of a company by determining the price of goods or services by an organizational unit from a company to other organizational units within the same company.

(3) From a tax perspective, transfer pricing is a pricing policy in transactions carried out by related parties. Arnold and McIntyre explain that the transfer price is the price determined by taxpayers when selling, buying, or sharing resources with affiliates.

In general, many multinational companies abuse transfer pricing, because the company has bad intentions, because it tries to transfer taxable income from a company in a multinational group of companies to another company in the same group of companies in a country that has a lower tax rate. This is done in order to reduce the total tax burden of the multinational group of companies.

Transfer pricing is regulated in the Director General of Taxes Regulation Number 32 of 2011. The regulation states the definition of the arm's length principle, namely the price or return on transactions carried out by unrelated parties is determined by market 
forces, so that the transaction reflects the market price natural. With the existence of regulations on Transfer Pricing, not all companies have bad connotations, so it needs to be fully understood.

\subsection{Income Tax}

Article 18 paragraph (3) of the Income Tax Law Number 36 of 2008 stipulates:

The Directorate General of Taxes has the authority to re-determine the amount of Taxable Income for Taxpayers who have special relationships with other Taxpayers in accordance with the reasonableness and practice of business that is not influenced by special relationships (arm's length principle) by using the price comparison method between independent parties, the method resale price, cost-plus method, or other method.

Article 18 paragraph (4): A special relationship is said to occur if

(1) Taxpayers have direct or indirect equity participation of at least $25 \%$ in other Taxpayers;

(2) Taxpayers control other Taxpayers or two or more Taxpayers are under the same control, either directly or indirectly; or (iii) there is a family relationship either by blood or by blood in a straight line and / or one degree to the side. Further regulations and details regarding transfer pricing are contained in the Directorate General of Taxes Regulation.

\subsubsection{Special Relationship}

In the background has been explained about a special relationship. In fact, this relationship arises when there are parties related to the business between the tax payer and the recipient taxpayer. This can occur if there are routine transactions between the two parties. Routine transactions between the two parties are in the form of buying, selling, or giving other compensation in whatever name and form.

The definition of a special relationship in taxation is defined as a business relationship that occurs between two or more taxpayers, which ultimately results in less payable income tax than it should be.

According to the Regulation of the Minister of Finance of the Republic of Indonesia Number 213 / PMK.03 / 2016 (hereinafter abbreviated as PERMENKEU), regarding the types of documents and / or additional information that must be kept by taxpayers conducting transactions with parties who have a special relationship, and the procedures for their management, issued on December 30, 2016, determined: Article 1

In this Ministerial Regulation what is meant by:

1. Special Relationship is a special relationship as stipulated in Article 18 paragraph (4) of Law Number 7 of 1983 concerning Income Tax as amended several times, most recently by Law Number 36 of 2008 concerning the Fourth Amendment of Law Number 7 of 1983 regarding Income Tax or Article 2 paragraph (2) of Law Number 8 of 1983 concerning Value Added Tax and Sales Tax on Luxury Goods as amended several times, most recently by Law Number 42 of 2009 concerning Third Amendment of Law Number 8 of 1983 regarding Value Added Tax and Sales Tax on Luxury Goods.

2. Affiliated Party is a party that has a Special Relationship with a Taxpayer.

3. Affiliated Transactions are transactions conducted by Taxpayers with Affiliated Parties.

4. The Principles of Fairness and Business Normality that are not Affected by a Special Relationship, hereinafter referred to as the Principles of Fairness and Business Normality, are the principles that govern that in terms of conditions in transactions between parties having a Special Relationship are the same or proportional to the conditions in transactions conducted between the parties that do not have a special relationship that are used as a comparison, the price or profit in the transaction between the parties who have a special relationship must be the same as or within the price range or profit range in the transaction between parties who do not have a special relationship which served as a comparison.

5. Transfer Pricing or Transfer Pricing, hereinafter referred to as Transfer Pricing, is the determination of the price in an Affiliated Transaction.

6. Transfer Pricing Documents are documents maintained by taxpayers as the basis for the application of the Fairness and Business Customary Principles in the determination of transfer prices made by taxpayers.

7. Business Group is a group of tax subjects who carry out business activities, which consists of parties having Special Relationships.

8. The Parent Entity is a member of a Business Group that meets the following criteria:

a. control directly or indirectly one or more other members in a Business Group; and

b. Has an obligation to prepare consolidated financial statements based on financial accounting standards applicable in Indonesia and / or based on regulations that bind stock exchange issuers in Indonesia.

So a legal entity that carries out transfer pricing because of a special relationship must make a clear overview of the ownership and reach of the affiliated countries. Fair price does not depend on any special relationship. 
A study of special relationship is considered to occur if the ownership relationship is in the form of equity participation, either directly or indirectly of $25 \%$ or more.

There are several things that occur in a special relationship, including:

(1) Effort

There is a transaction between the granting taxpayer and the recipient taxpayer, where the transaction occurs routinely, in the form of sales, purchases, or other gifts in whatever name and form.

(2) Work.

The relationship between the parties concerned with respect to the work of the taxpayer providing the taxpayer with the receiving Taxpayer in the form of employment, provision of services, or implementation of activities directly or indirectly between the two parties.

For example:

Suppose A works as a gold company marketing, and he has the task of marketing PT. ABC, although he is not an employee of PT. ABC, but between A and PT. ABC is considered to have a special relationship, even though it is an indirect employment relationship, so that A's income received from $\mathrm{PT}$. ABC is an object of income for A because it has an indirect employment relationship.

\section{(3) Ownership or Equity Participation}

A special relationship is considered to occur if the ownership relationship is in the form of equity

Participation, either directly or indirectly of $25 \%$ or more.

For example:

a. Direct Inclusion

PT. ABC owns $35 \%$ of shares in PT. XYZ. The share ownership of PT XYZ by PT ABC is a direct equity participation of more than $25 \%$.

b. Indirect Inclusion

If PT. ABC owns 50\% of PT. XYZ, then PT. Q as a shareholder in PT. ABC indirectly has equity participation in PT. XYZ at 25\%. Between PT ABC, PT.Q and PT. XYZ has a special relationship.

(4) Mastery, Either Through Management or Use of Technology

A special relationship between entrepreneurs (taxpayers) can also occur because of control through management or use of technology. A special relationship occurs when one or more companies are under the same control.

\section{For example:}

\section{a. Mastery through management}

Mrs. X is the main director at PT. A, oa also concurrently serves as the President Director at

PT. B. In this case there is a special relationship between PT. A and PT. B, because of the mastery in management through A to PT. A and PT. B.

\section{b. Mastery through the Use of Technology}

PT. A is a drug factory that produces Covid - 19 drugs, which is currently sweeping the world, but the formula / recipe is a creation of PT. B.

So in this case it can be said that there is control over the use of technology by B against the company PT. A. Because what is listed in the drug package is the property of PT. B, did not discuss the problem made by the company PT. A, but the formula for PT.B as the responsible party. Of course there is a reward from PT. B to PT. A on a regular basis, then this has a special relationship, and the reward is an object of income tax.

To be clearer, it is necessary to explain further as follows:

\subsubsection{Work-related}

The relationship between the parties concerned with respect to the work between the granting taxpayer and the recipient taxpayer occurs when there is a direct or indirect relationship in the form of employment, service provision or implementation of activities between the two parties.

Example:

(1) Mr. X is the director of PT. ABC and Mr. Y are employees of PT. DEF. In this case, PT. ABC with Mr. X and / or Mr. Y receiving assistance or donations from $\mathrm{PT} . \mathrm{ABC}$ or vice versa, then the assistance or contribution is an object of Income Tax for those who receive it because PT. ABC with Mr X and / or Mr Y has a direct employment relationship. 
(2) Mr. A works as an outside insurance officer for the insurance company PT. XYZ. Even though Mr. A is not an employee of PT. XYZ, but between PT. XYZ and Mr A are considered to have an indirect employment relationship. If Mr. A receives assistance or donations from $\mathrm{PT}$. XYZ or vice versa, the aid or contribution is an object of Income Tax for the party receiving it because PT. XYZ and Mr. A have a special relationship.

\subsubsection{Ownership or Equity Participation Relationship}

A special relationship between the parties concerned with respect to ownership or control between the tax payer and the recipient taxpayer occurs when there is ownership or equity participation; or there is control through management or the use of technology. In addition, a special relationship between individual taxpayers can also occur because of blood or marriage relations.

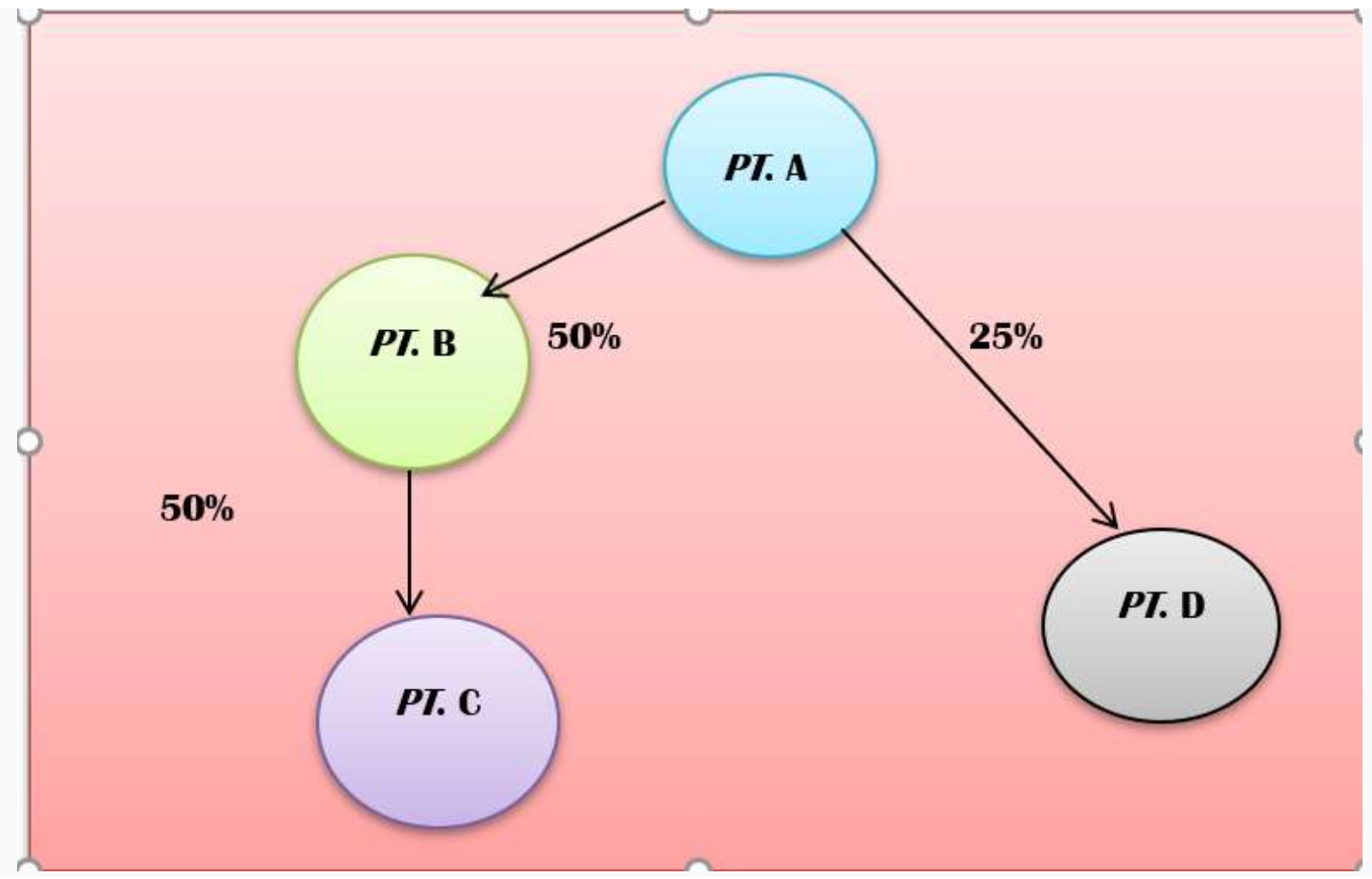

Figure 1: Equity Participation Relationship

Source: research results

Starting with Article 18 paragraph (4) of Law No. 36 Year 2008:

The special relationship referred to in paragraph (3) to paragraph (3d), Article 9 paragraph (1) letter (1) is deemed to exist if:

a. Taxpayers have direct or indirect equity participation of at least $25 \%$ in other taxpayers; relationship between the Taxpayer and the participation of at least $25 \%$ in two or more Taxpayers; or the relationship between two or more of the latter taxpayers.

Example:

Limited Liability Company A owns $50 \%$ of shares in Limited Liability Company B, share ownership by Limited Company A is direct participation. Furthermore, if Limited Company B owns $50 \%$ of the shares of Limited Liability Company C, Limited Liability Company A as the shareholder of Limited Liability Company B indirectly has $25 \%$ participation in Limited Liability Company C. In such a case, between Limited Liability Company A, Limited Liability Company B and Limited Liability Company C, it is considered that there is a special relationship. If Limited Company A also owns $25 \%$ of shares in Limited Liability Company D, between Limited Liability Company B, Limited Liability Company $\mathrm{C}$ and Limited Liability Company D, it is considered that there is a special relationship. The ownership relationship as above can also occur between an individual and a legal entity.

b. Taxpayers control other taxpayers or two or more taxpayers are under the same control, either directly or indirectly; or a special relationship among taxpayers can also occur because of control through management or use of technology even 
though there is no ownership relationship. A special relationship is considered to exist if one or more companies are under the same control. Likewise, the relationship between several companies that are under the same control.

Example:

(1) Direct management control

Mr. A and Mr. B are directors of PT. X, while Mr. C is a commissioner of PT. X. In addition, Mr. C is also a director at PT. Y, and Mr. B as commissioners at PT. Y. Mr. B junior is the director of PT. AB, while Mr. E as commissioner of PT. AB. Mr. B Junior is the son of Mr. B who is the director of PT. X and commissioners of PT. Y.

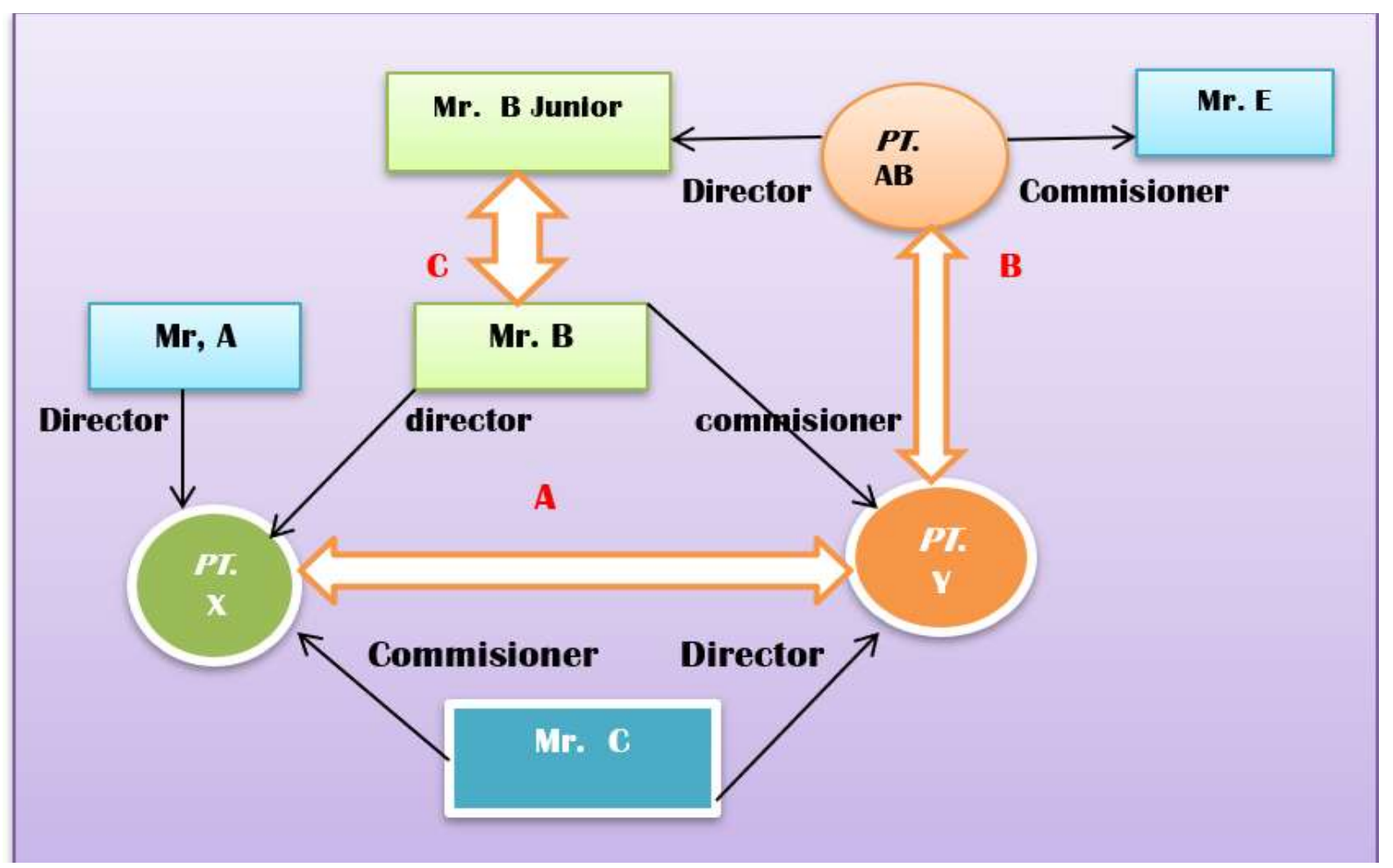

Figure 2: Direct Relationship

Source : Research Result

Caption :

A. Between Limited Liability Company X and Limited Liability Company $\mathrm{Y}$ has a direct management control relationship, because Mr. B in addition to working as a director in Limited Liability Company X also works as a commissioner of Limited Liability Company Y. In addition, Mr. C besides working as a commissioner in Limited Liability Company X also works as a director in Limited Liability Company Y. If Limited Liability Company $\mathrm{X}$ receives assistance or donations from Limited Liability Company $\mathrm{Y}$ (or vice versa) then the assistance or contribution is subject to tax for the recipient.

B. Between Limited Liability Company Y and Limited Liability Company AB has a direct management control relationship, because there is a family relationship between Mr. B (father) who works as a commissioner in Limited Liability Company Y and Mr. B junior (son) who works as a director in the Limited Liability Company. $\mathrm{AB}$. If Limited Liability Company $\mathrm{AB}$ receives assistance or donations from Limited Liability Company Y (or vice versa) then the assistance or contribution is a tax object for the receiving party.

C. If Mr. B Junior (child) receives assistance or donations or gifted assets from Mr. B (father), the aid or donations or gifted assets are exempted from the income tax object as referred to in Article 4 paragraph (3) letter a of the Income Tax Law, because those who have a management control relationship are between Limited Liability Company Y and Limited Liability Company AB, not between Mr. B (father) and Mr. B Junior (son). Thus, management tenure relationships only occur between entities that have the same management or have family relationships. Meanwhile, the management in the entity does not have a control relationship. 


\section{Example:}

Indirect Management Control

Mr. A is the director of the Limited Liability Company XYZ and Mr. B is the commissioner of the Limited Liability Company XYZ, Mr. A and Mr. B clearly have the authority to determine policies and. or take decisions in order to carry out DEF Limited Liability Company activities, for example the right to sign a contract with a third party, sign a check, etc. even though Mr. A and / or Mr. B are not listed by name in the composition of the management stated in the deed of establishment or deed of change of PT. DEF. In this case, Limited Liability Company XYZ and Limited Liability Company DEF have an indirect management control relationship. If the DEF Limited Liability Company receives assistance or donations from Limited Liability Company $\mathrm{XYZ}$ or vice versa, the assistance or contribution is a tax object for the receiving party.

\subsection{FAIR VALUE DISCLOSURES IN TRANSFER PRICING TO TRANSACTIONS}

Gunadi (2009: 280) Transfer Pricing between countries involves various consideration variables such as taxes, tariffs (import duties), competition, inflation rates, foreign exchange rates, fund transfer restrictions, political risks and the interests of business partners making policy complications.

Often between the taxpayer as the seller and the taxpayer as the buyer makes transactions with an unreasonable value, but behind all this, the taxpayer as the seller and the taxpayer as the buyer has agreed the real price, because the price paid by the buyer The seller's taxpayer does not match what is written. This is to avoid paying high taxes.

Gunadi, (1994: 9) Transfer price is the determination of the price or reward in connection with the delivery of goods, services or technology transfer between companies that have a special relationship.

Lumbantoruan (1996: 26) Transfer price is the determination of the remuneration price for a transaction between units within a company or between units within a company or between companies in a group

Blocher (1999: 11) Transfer price is the determination of the exchange price when different business units in a company exchange products or services. These products may be end products which can be sold to outside customers or intermediate products which are components of the final product.

This can be ascertained that there is a special relationship between taxpayers and will have an impact on the taxation aspects of each party with a special relationship. This special relationship affects taxation, especially Article 18 paragraph (4) of the Income Tax Law and Article 2 paragraph (2) of the VAT Law.

According to Charles T Horngren and Gary L. Sundem Transfer prices can be pejorative, transfer prices are the amount charged by one segment of an organization for a product that it supplies to another segment of the same organization in multinational companies, transfer prices are used to minimize worldwide income taxes and import duties. (Suandy, 2011: 71)

Gunadi (1994: 11) Transfer price is an engineering manipulation of prices systematically with the aim of reducing artificial profits, making it appear that the company is losing money, avoiding taxes or duties in a country.

To avoid fraud by Taxpayers in conducting transactions, the Directorate General of Taxes has the authority :

To redetermine the amount of income and deduction and determine debt as capital to calculate the amount of taxable income for a Taxpayer who has a special relationship with other Taxpayers in accordance with the fairness and common practice of business that is not affected by a special relationship by using the price comparison method. an independent party, the resale price method, the cost-plus method, or any other method;

\section{The meaning:}

The implementation of this provision is to prevent tax evasion that may occur because of a special relationship. If there is a special relationship, there is a possibility that the income is reported less than it should be or the cost is more than what it should be. In such a case, the Directorate of Taxpayers has the authority to redetermine the amount of income and / or expenses according to the circumstances if there is no special relationship among the taxpayers. In determining the amount of income and / or expenses, among others are used:

- Comparable uncontrolled price method

- Resale price method;

- The cost-plus method (cost-plus method); or

- Other methods such as the profit split method and;

- Transactional net profit method (transactional ner margin method)

So there is a possibility that there is capital participation in disguise, by stating the capital participation as debt, the Directorate General of Taxes has the authority to determine the debt as company capital. This determination can be made through an 
indication of the comparison between capital and debt that is common among parties who are not affected by a special relationship or based on data or other indications.

Therefore, the interest paid in connection with the debt which is considered as equity participation is not allowed to be deducted, while for shareholders who receive or earn the interest it is considered a taxable dividend.

(1) To enter into an Agreement in Determining the Transaction Price.

The Directorate General of Taxes has the authority to enter into agreements with taxpayers and cooperate with tax authorities in other countries to determine the price of transactions between parties who have a special relationship, which is valid for a certain period and supervises its implementation as well as undertakes certain renegotiations and supervises its implementation and renegotiates after that certain period ends.

Advance Pricing Agreement is an agreement between the Taxpayers and the Directorate General of Taxes regarding the fair selling price of the products they produce to parties who have a special relationship (related parties) with them. The purpose of holding transfer pricing / transfer prices is to reduce the occurrence of misuse of transfer pricing by multinational companies. The agreement between the Taxpayer and the Directorate General of Taxes can cover several things, including:

- The selling price of the products produced;

- Amount of royalty and others, depending on the agreement.

The advantages of transfer pricing apart from providing legal certainty and ease of tax calculation, tax authorities do not need to make corrections to the selling price and profit of products sold by taxpayers to companies in the same group. Transfer pricing is unilateral, which is an agreement between the Director General of Taxes and Taxpayers or bilateral, namely an agreement between the Directorate General of Taxes and the taxation authorities of other countries concerning Taxpayers who are in its jurisdiction.

\section{(2) To Determine the actual Party.}

Taxpayers who purchase shares or company assets through other parties or entities that are formed for this purpose (special purpose company) can be determined as the actual party making the purchase as long as the taxpayer concerned has a special relationship with the other party or entity and there is an irregularity pricing.

\section{(3) To Designate as a Seller}

The sale or transfer of shares in a conduit company or special purpose company that is established or domiciled in a country that provides tax protection (tax haven country) which has a special relationship with an entity established or domiciled in Indonesia or a permanent establishment in Indonesia may stipulated as a sale or transfer of shares of an entity that is established or domiciled in Indonesia or a permanent establishment in Indonesia.

Example:

A Ltd which was founded and domiciled in Country X, a country that provides tax protection (tax haven country) owns 95\% of PT. A who was founded and domiciled in Indonesia. A Ltd is a conduit company that is fully established and owned by B Co., a company in Country $\mathrm{Y}$ with the aim of being an intermediate company in its ownership of the majority of shares in Limited Liability Company A. If B Company sells all of its ownership in A Limited's shares to Limited Liability Company $\mathrm{C}$ which is a resident Taxpayer, legally the above transaction constitutes a transfer of shares in the foreign company by the foreign taxpayer. However, in essence this transaction is a transfer of ownership (shares) of the domestic taxpayer by a foreign taxpayer, so that the income from this transfer is payable Income Tax.

\section{(4) To determine the amount of income again.}

The amount of income obtained by an individual resident Taxpayer from an employer who has a special relationship with another company which is not established and is not domiciled in Indonesia can be re-determined, in the event that the employer transfers all or part of the income of the resident individual Taxpayer to the country. in the form of fees or other expenses paid to companies that are not established and are not domiciled in Indonesia.

In order to simplify and realize the authority to determine transfer prices by the Directorate General of Taxes, the Minister of Finance Regulation Number 213 / PMK.03 / 2016 was issued, which determines the reporting of master documents, local documents and country-to-country reports for taxpayers who make transactions with parties have a special relationship. This is in line with the Organization for Economic Co-operation and Development (OECD) in its final report on Transfer Pricing Documents and Country - by - Country Reporting - Action 13 (also known as BEPS Action 13). So this regulation introduces a 3 tier approach to documentation requirements that is in line with BEPS Action 13, namely:

- Use of threshold for document management; 
- $\quad$ Require documents to be made in Indonesian;

- The party that is obliged to maintain the document, the information that should be included in the document and when the document should be available

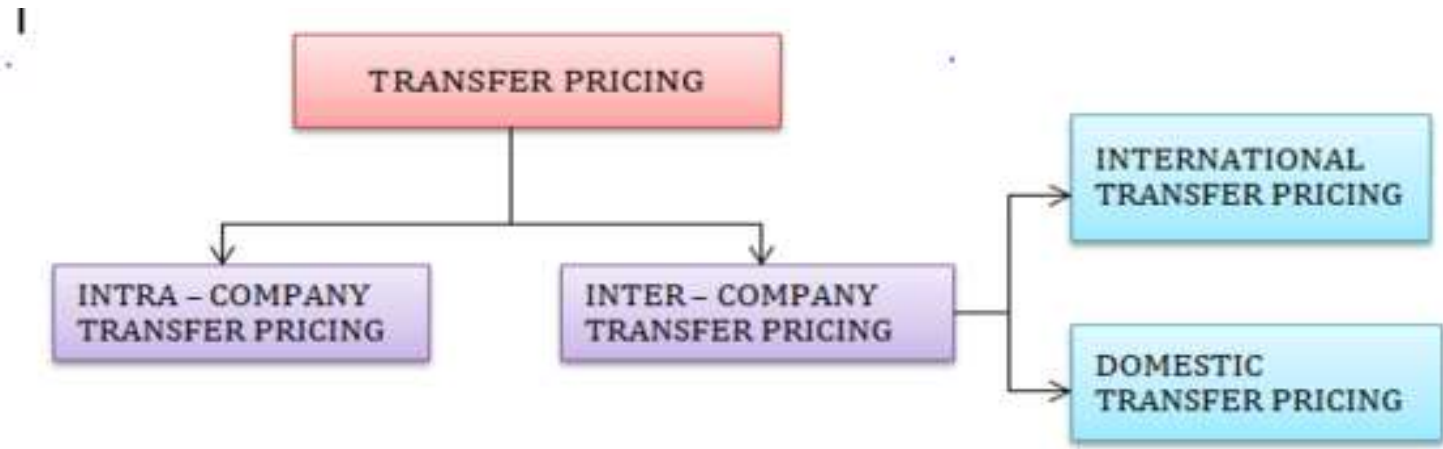

Figure 3: Transfer Pricing Flowchart

Source: Research Result

\subsection{JUSTICE THEORY}

According to Rescher (1968: 25), in Lebacqz (2015: 35) a new action is considered right and fair if distributed / distributed equally, which is known as distributive justice, which lies in giving to the community according to legal claims. If the distribution doctrine does not comply with statutory provisions, it is invalid.

Rawls (1971: 220) states two (2) principles of the theory of justice:

(1) The same freedom.

Freedom is the right of everyone to obtain it equally over the most extensive and compatible total system for all.

(2) Social inequality.

Between social and economy must be balanced, so that both have the greatest benefit expected and there are

Conditions of equality of opportunity that is just. (1971: 72)

Freedom is the right of everyone, so everyone must have the same rights. Social and economic disparities must be overcome, so that it is beneficial for Taxpayers and gets equal, equal opportunities and justice.

This theory of justice is very basic to tax collection, without justice, tax collection can be considered as a confiscation of people's property, so that the taxpayer pays taxes, but the government must provide benefits that can be enjoyed by the taxpayers, to be fair.

According to Mill (1957: 10) in Karen Lebacqz (2015:38) saying that the main idea of utilitarian ideas is very simple, namely to produce the greatest good for the right, because ideas are one way for humans to issue ethical decisions. So this theory has the power. incredible pull.

Mardiasmo (2011) states that tax collection must meet and comply with the objectives of law and law, so that tax collection does not cause obstacles or resistance, in order to achieve justice.

According to Article 23 paragraph (2), tax collection must be based on law as a juridical requirement in Indonesia, which in essence, the State provides legal guarantees to declare justice, for all its citizens. This is a manifestation to reflect a sense of justice for Taxpayer.

From the juridical aspect, compliance and justice have brought legal consequences for taxpayers, the General Taxation Provisions will be guaranteed to be implemented properly and correctly, as well as all regulations from the Ministry of Finance regarding transfer pricing can be monitored properly, because the taxation system is advanced, all using advanced technology, so that any taxpayer violations related to tax payments will be easily detected, so sanctions must be strictly applied, as a way to test taxpayer compliance. Thus in the future, the taxpayer violations can be reduced and can be resolved easily.

Transfer pricing without being followed by enforcement of sanctions will be useless and taxpayers will not comply.

From the above explanation, it raises a new hope for both the Government and the taxpayer, namely the existence of value, as expressed by Klandersman (1984). 


\subsection{MOTIVATION THEORY}

Klandersman (1984) says: "individual's behavior is a function of the value of expected outcomes of behavior". So the value function is the result of a person's behavior and is the expected result of an action. Post-tax amnesty, it is hoped that the taxpayers' behavior will obey and no longer repeat the same mistakes.

Motivation is defined as the urge to act to achieve a specific goal. The results of this motivation and movement are manifested in the form of behavior.

Maslow's theory assumes that people in power fulfill more basic (physiological) needs before directing behavior to fulfill higher needs (self-realization). ... So when a need reaches its peak, that need will cease to be the main motivation for behavior.

So someone who has high needs, will influence the mind, eventually change behavior, can deviate or violate the rules for their own interests. Likewise, a multinational company that is represented by its management organs, can have certain goals and objectives for the benefit of the company, so transactions are carried out through transfer pricing, at an unreasonable price, so that the tax to be paid is smaller than it should be. This depends on the perpetrator's motivation, so that it can change his actions.

Motivation can be defined as encouragement that directs oneself to behave in actions to achieve the desired goals. There is certainly motivation to move someone so that there is a desire or willingness to do something that ultimately achieves these goals and objectives. Many companies run parts of their lives with encouragement or motivation, whether it comes from others or themselves, whether positive or negative motivations.

The theory of motivation from Herzberg, motivation is important, because motivation will help humans in living their lives, needs and human personality. The existence of motivation is a driving force in every activity carried out and setting aside actions that are not useful for the goals to be achieved. In carrying out work, there must be factors that influence it. The world of work is of course very closely related to satisfaction and dissatisfaction, be it satisfaction in terms of material or performance. This means that job satisfaction and dissatisfaction are related to one another. Likewise, a company, which is controlled by its organs, which represents a human being, is of course influenced by the work environment, satisfaction with income, satisfaction with work, and disregard for the burden of paying taxes to the State. This is what causes the abuse of transfer pricing, because price transactions become unreasonable, and consequently detrimental to the state, because tax payments to the state are smaller than they should be. This depends on the motivation of the manager, so it affects their behavior.

McClelland (The Achievement Motive, 1953) suggests that individuals have reserves of potential energy, how this energy is released and developed depends on the strength or motivation of the individual and the situations and opportunities available.

This achievement motivation theory focuses on three needs, namely:

\section{a. Need for Achievement}

The need for achievement is the drive to excel, to excel in terms of a set of standards, to wrestle for success. The characteristics of individuals who show high orientation include being willing to accept a relatively high risk, a desire to get feedback about their work, a desire to take responsibility for problem solving.

\section{b. The Need for Power}

The need for power is the need to make other people behave in a way where those people without being forced will not behave that way or a form of expression from the individual to control and influence others.

McClelland stated that the need for power is closely related to the need to achieve a leadership position.

\section{c. Need for Affiliation}

The need for affiliation or friendship is the desire for friendly and intimate interpersonal relationships. Individuals reflect a desire to have a close, cooperative and friendly relationship with other parties. Individuals who have a high need for affiliation generally succeed in jobs that require high social interaction.

McClelland said that most people have a combination of these characteristics, the consequences of which will affect employee behavior in working or managing the organization.

The characteristics and attitudes of achievement motivation according to McClelland are:

a. Achievement is more important than material.

b. Accomplishing a goal or task provides greater personal satisfaction rather than receiving praise or recognition.

c. Feedback is very important, because it is a measure of success (feedback feedback that is reliable, quantitative and Factual). 


\section{RESEARCH METHOD}

Is a scientific process or way to obtain data that will be used for research purposes. The methodology is also a theoretical analysis of a research method or method, which is a systematic investigation to increase a number of knowledge, it is also a systematic and organized effort to investigate certain problems that require answers.

The nature of research can be understood by studying various aspects that encourage research to conduct research. Everyone has different motivations, some of which are influenced by their respective goals and professions. Motivation and research objectives in general are basically the same, namely that research is a reflection of the desire of humans who are always trying to know something. The desire to acquire and develop knowledge is a basic human need which generally becomes the motivation for conducting research.

\subsection{Objective of research}

According to Moleong (2005: 6), qualitative research is research that intends to understand the phenomena experienced by research subjects such as behavior, perception, motivation, action, etc. holistically, and by means of descriptions in the form of words and language., in a special context that is natural and by making use of various natural methods. Therefore, the purpose of this study is to explain the phenomena that occur in society in depth by collecting data in depth and completely. This shows that in this research the completeness and depth of the data being studied is very important.

\subsection{Type of Reseach}

Legal research is a scientific activity based on methods, systematics and certain thoughts, which aim to study one or more specific legal phenomena by analyzing them.

Apart from that, there is also an in-depth examination of legal facts, to then seek a solution to the problems that arise in the symptoms concerned.

Before conducting legal research, it is necessary to understand the scope of legal discipline. Legal discipline is a system of teaching about law as a norm, that is, something that is aspired to and as a reality or attitude of action.

This Normative legal research method is also commonly referred to as doctrinal legal research or also called library research. It is called doctrinal law research, because this research is only aimed at written regulations so that the research is very closely related to libraries because this normative law will require secondary data in the library.

In a written legal normative legal research, it is also examined from various aspects such as aspects of theory, philosophy, comparison, structure or composition, consistency, general explanation and explanation of each article, the formality and strength of binding a law and the language used is legal language. . So it can be concluded that normative legal research has a very broad scope.

\subsection{Data Collection Technique}

Starting with coding. Coding is a basic step in the operationalization of qualitative data analysis. At the coding stage, it means that (initial) field data have been collected. It is possible that when they go to the field, the researchers will collect data again. Thus qualitative research tends to shape the circulation process in its analysis. 


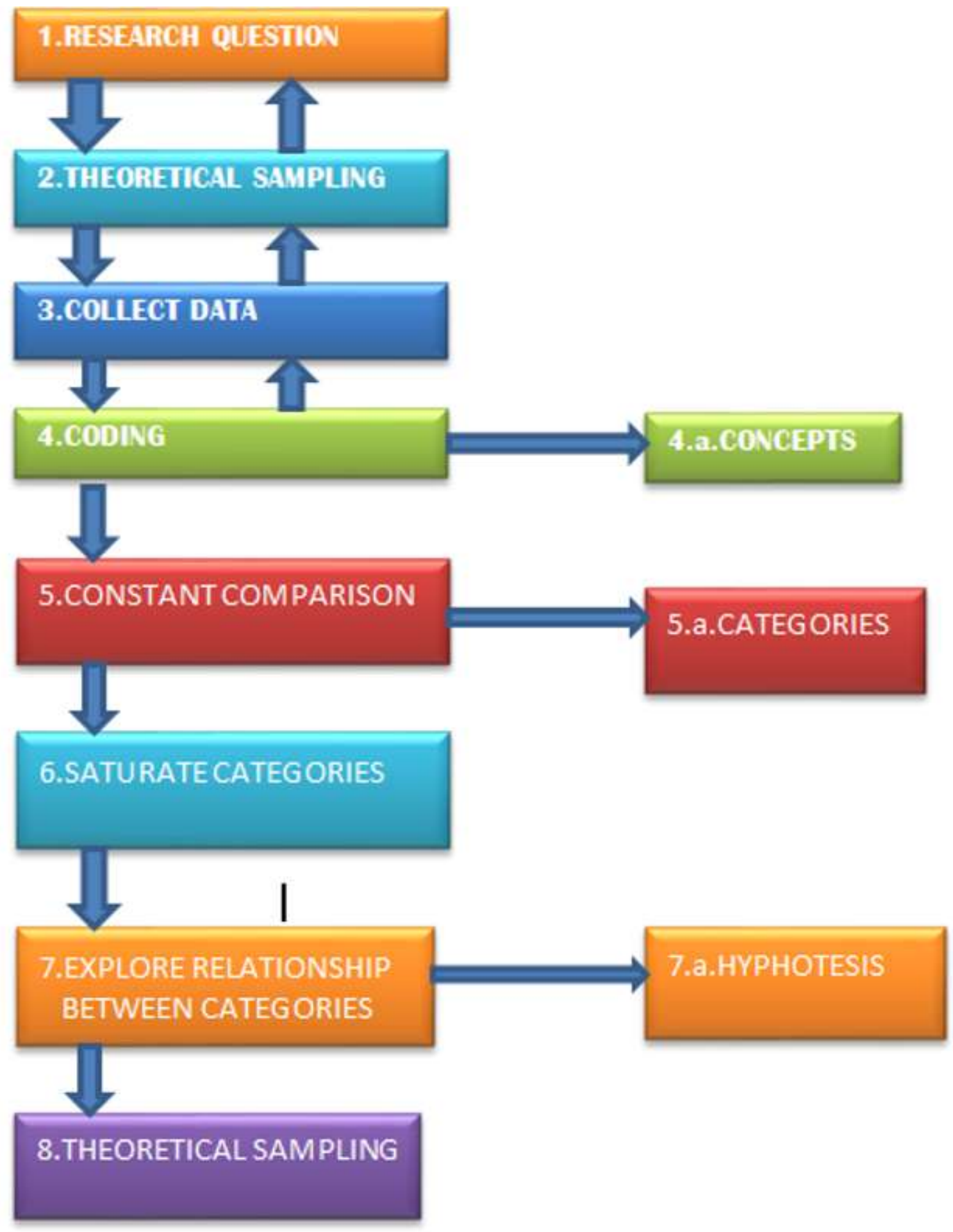

Figure 4 : Circulation Process

\section{Research Questions}

is a clear, focused, concise, complex and debatable question that is around the problem being discussed and becomes the main question of the research. Gaps that arise in writing, so that it becomes an issue of questions to be studied.

\section{Theoretical Sampling}

is a process in data collection, where the researcher collects, encodes, and analyzes, and determines what data needs to be collected next and where the data can be obtained, in order to develop a theory that is slowly starting to appear. 


\section{Coding, then proceed with drafting}

The results of data coding indicate that transfer pricing in multinational companies inspires many entrepreneurs to do so.

Multinational companies are companies that do business in many countries. These companies are usually very large, have offices, factories or branch offices in many countries. They usually have a headquarters where they coordinate global management.

Transfer pricing is a company policy in determining the transfer price for a transaction of goods, services, intangible assets, or financial transactions conducted by the company. There are two groups of transactions in transfer pricing, namely intracompany and inter-company transfer pricing.

\section{Constant Comparison๖ categories}

is a technique used by Grounded Theory researchers to abstract the various descriptive data collected.

The data then needs to be compared again with the previous data and the existing code.

After the concepts used are clear, the researcher can arrange categories. By listing which informant's statements are included in the transfer pricing, multinational and taxation literature, the researcher explores the relationship between each category and ensures that the data (usually in the form of text or narrative) fall into the appropriate category

\section{Saturate Categories}

From the categories that have been compiled, the researcher can make a hypothesis. For example, multinational companies that have carried out transfer pricing, this hypothesis shows that taxpayers benefit greatly, because the burden of paying taxes to the State is much smaller than if they do not carry out transfer pricing. This has been proven by the company.

\section{Explore Relationship Between Categories $\diamond$ Hypothesis}

As previously stated, qualitative data analysis is almost always not linear. Researchers go to the field, go to work again, go to the field again and so on to get quality results. Qualitative research has an emphasis on the quality of research results, not quantity. After the hypothesis is tested, the researcher can confirm existing theories, develop theories or create new theories. The results of the analysis are the results of studies that are ready to be tested and presented to the public.

\section{Theoretical Sampling}

is a process in data collection, where the researcher collects, encodes, and analyzes, and determines what data needs to be collected next and where the data can be obtained, in order to develop a theory that is slowly starting to appear.

\subsection{Research Subject}

In qualitative research, respondents or research subjects are referred to as informants, that is, people provide information about the data the researcher wants in relation to the research being carried out.

In this case the informant is a business actor in the form of a legal entity or a multinational company that carries out transfer pricing.

\subsection{Data Analysis Technique}

The focus of the research problem requires the researcher to conduct a systematic, in-depth, and meaningful study as confirmed by Burgess below. "In qualitative research, all investigators or researchers focus on the problem being studied, guided by a conceptual or theoretical framework" (Sudarwan Danim and Darwis, 2003: 262).

As an effort made by working with data, organizing data, sorting it into manageable units, synthesizing it, looking for and finding patterns, finding what is important and what is learned and deciding what to tell people

Data analysis technique is the process of systematically searching and arranging data obtained from interviews, field notes, and documentation, by organizing data into categories, breaking down into units, synthesizing, arranging into patterns, choosing which ones are important and will be studied, and make conclusions, so that they are easily understood by oneself and others.

\subsection{Research Stages}

Endang S Sedyaningsih Mahamit (2006) in Asep Suryana (2007: 5) the stages of qualitative research include:

(1) Determine the problem.

(2) Conduct a literature study.

(3) Determination of location.

(4) Preliminary study.

(5) Determining the data collection method; observation, interview, document, 
focus discussion.

(6) Analyze data during the study.

\section{RESULT AND DISCUSSION}

From what has been described above, get a result of thoughts and need to be discussed.

\subsection{Result}

Transfer pricing is a global issue, which is not only experienced by Indonesia, but throughout the world, so that the Directorate General of Taxes in Indonesia needs to take it seriously so that the country does not suffer losses by multinational companies. Multinational companies use transfer pricing for tax planning purposes, no longer for measuring the performance of company divisions. In fact, the purpose of transfer pricing is to evaluate the performance of the division, which will affect company profits.

\subsection{Discussion}

Fiskus must understand transfer pricing in a simpler way, namely the fairness of transaction prices that are influenced by a special relationship, and can explain transfer pricing to taxpayers more simply.

John Hutagaol said "formulating appropriate policies, drafting regulations, monitoring compliance both formal and material, to effective and efficient dispute resolution," This was conveyed at the National Forum event on August 25-28, 2020 organized by the Directorate General of Taxes.

The results of the discussion resulted in 2 (two) things that need to be applied in transfer pricing, namely:

(1) Strategies for monitoring compliance and exploring potential transactions, including how the Director General of Taxes will design and use the means to detect tax avoidance risks through transfer pricing using data held by the Directorate General of Taxes.

(2) It is necessary to observe and identify regulations and handling of transfer pricing in an effective and efficient international tax dispute resolution effort.

Tax Magazine | Building a Synergy in Transfer Pricing Handling, accessed on 11 January 2021 (Majalah Pajak/Membangun Sinergi Penanganan Transfer Pricing, di akses tanggal 11 Januari 2021)

The resulting regulations can be a driving force for economic activity and investment, so the legal certainty of transfer pricing regulations for business actors needs to be realized, because it is an important factor in carrying out business activities.

\section{CONCLUSION AND SUGGESTION}

\subsection{Conclusion}

What has been described in the background, as well as in the discussion, then comes a conclusion that answers the problem, namely:

(1) The emergence of a special relationship between taxpayers can occur because of dependence or attachment to one another, whether directly or indirectly related to business, work or ownership or control. Related to ownership or control consists of 3 (three) things, namely:

a. Taxpayers have direct or indirect equity participation of at least $25 \%$ in other taxpayers; relationship between the Taxpayer and the participation of at least $25 \%$ in two or more Taxpayers; or the relationship between two or more of the latter taxpayers;

b. Taxpayers control other Taxpayers or two or more Taxpayers are under the same control, either directly or indirectly;

c. There is a family relationship, both blood and blood, in a straight line and / or one degree to the side.

(2) Disclosure of the actual "Fair Value" in transactions or business activities between taxpayers as sellers and taxpayers as buyers will occur if the Directorate General of Taxes is suspicious of an unreasonable or unusual transfer price, because:

a. Multinational companies with the intention of allocating income from one company to another company in a different country within the multinational company with the aim of reducing taxable profit in countries that have high tax rates and transferring their profits in other countries with low or even zero tax rates;

b. Allocating income to countries that do not have anti-tax avoidance regulations, so that multinational companies can easily determine the price of goods, services or intangible assets for tax avoidance purposes.

So the Tax Directorate has 5 (five) powers related to transfer pricing for transactions between taxpayers as sellers and buyers who have a special relationship. 


\subsection{Suggestion.}

Taxpayers should act honestly in carrying out transfer pricing, so it must be neutral, namely the transfer price is purely a business strategy and tactic without a tax burden reduction motive. Do not let taxpayers carry out pejorative transfer pricing, meaning that it assumes transfer prices as an effort to save tax burdens with tactics, including shifting profits to countries with low tax rates.

\section{REFERENCES}

1. Darussalam and Danny Septriadi. 2008. Cross-Border Concepts and Applications Transfer Pricing For Taxation Purposes. Danny Darussalam Tax Center. Jakarta

2. Blocher, Edward, et al., (1999), Cost management, A Strategic Emphasis, USA: McGraw-Hill.

3. Gunadi, (2009), Tax Accounting, Grasindo, Jakarta

4. Gunadi, (1994), Transfer Pricing An Overview of Management Accounting and Taxes, Jakarta, Bina Rena Pariwara,

5. Herzberg, Frederick, 2001, Motivation - Hygiene Theory and the $21^{\text {st }}$ Century Workforce, author Jennifer Danback,

6. Mercy College (Dobbs Ferry, N.Y), Mercy College Publisher.

7. Lumbantoruan, Sophar., (1996) Tax Accounting, Revised Edition, Grasindo, Jakarta

8. McClelland, David Clarence (1953), The Achievement Motive, New York, Appleton-Century-Crofts, 1953

9. Prianto Budi S. 2012. Transfer Pricing Documentation. presented at Hotel VUE PALACE Bandung on February 20, 2012

10. Suandy, Erly (2011), Tax Planning, 5th Edition, Jakarta: four salemba

\section{ANNEXURE}

\section{LAWS AND REGULATIONS:}

1. Law - UU R.I. No. 36 of 2008, passed in Jakarta, on 22 September 2008, by

a. the President of the Republic of Indonesia, promulgated in Jakarta, on 23 September 2008, by the Minister of Law and Human Rights of the Republic of Indonesia, State Gazette of the Republic of Indonesia, 2008 Number 133.

2. General Provisions for Taxation Number 28 of 2007, ratified in Jakarta, on July 17, 2007, by the President of the

a. Republic of Indonesia, promulgated in Jakarta, on July 17, 2007, by the Minister of Law and Human Rights of the Republic of Indonesia, State Gazette Republic of Indonesia of 2007 Number 85 in conjunction with Law Number 16 of 2009

3. Presidential Decree No 56/2010

4. Regulation of the Minister of Finance of the Republic of Indonesia. No. 139 / PMK.03 / 2010 dated 11 August 2010

a. concerning private domestic taxpayers from employers who have Special Relationships with other companies that are not established and are not domiciled in Indonesia;

5. Regulation of the Minister of Finance of the Republic of Indonesia. 140 /PMK.03 / 2010, dated 11 August 2010

a. concerning Determination of the taxpayer as the party who actually purchases the shares or assets of the company through another party or an entity established for this purpose (special purpose company) which has a special relationship with other parties and there is a price fixing irregularity. 
6. Republic of Indonesia Government Regulation Number 94 of 2010 dated 30

a. December 2010 concerning the Calculation of Taxable Income and Repayment of Income in the Current Year, dependence or commitment can be done directly or indirectly with respect to business, work, or ownership or control, carried out by the parties concerned;

7. Regulation of the Director General of Taxes No PER - 32 / PJ / 2011 dated 11 November 2011 concerning the

a. Application of Fairness and Business Usual Principles in transactions between taxpayers and related party rights

8. Regulation of the Minister of Finance of the Republic of Indonesia. No 7 / PMK.03 / 2015 dated 12 January 2015

a. concerning procedures for establishing and implementing an Advance Pricing Agreement;

9. Regulation of the Minister of Finance of the Republic of Indonesia. No. 213 / PMK.03 / 2016, dated 30 December 2016

a. concerning types of documents and / or additional information that must be kept by the taxpayer who conducts transactions with related parties, and the procedures for their management;

10. Ministry of Finance Regulation (PMK) Number. 22 / PMK.03 / 2020 (PMK)

a. concerning Procedures for Implementing Advance Pricing Agreement, Determined Date. 18 March 2020.

11. www.http//: wibowopajak.com, visited on 15 December, 2018

12. https://solusibisnis.co.id/pentingnya-memahami-transfer-pricing-dan-bagaimana-mengantisipasinya.htm visited on 15

a. August, 2019

13. http://ortax.org/tpdoc/index_preparing.html, visited on 15 August, 2019

14. https://taxstudium.blogspot.com/2012/10/arms-length-principle-1.html, accessed date on 1 January, 2021

15. https://www.ortax.org/ortax/?mod=issue\&page=show\&id=74, accessed date on 11 January, 2021

16. Majalah Pajak Membangun Sinergi Penanganan Transfer Pricing, accessed date on 11 January, 2021 